ISSN 0974-3618 (Print) 0974-360X (Online) www.rjptonline.org

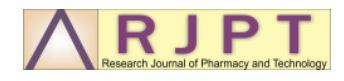

RESEARCH ARTICLE

\title{
Detection of the Calcium and ATP Role in Apoptosis of Retinoblastoma Culture Cells through Caspase-3 Expression
}

\author{
Hendrian D. Soebagjo*, Susy Fatmariyanti' ${ }^{1}$, Paulus Sugianto², Bambang Purwanto ${ }^{3}$, \\ Ugroseno Y. Bintoro ${ }^{4}$, Endang R. Kusumowidagdo ${ }^{5}$ \\ ${ }^{1}$ Department of Ophthalmology, Faculty of Medicine, University of Airlangga, Dr. Soetomo General Hospital \\ Surabaya, Surabaya, East Java, Indonesia. \\ ${ }^{2}$ Department of Neurology, Faculty of Medicine, University of Airlangga, Dr. Soetomo General Hospital \\ Surabaya, Surabaya, East Java, Indonesia. \\ ${ }^{3}$ Department of Phisiology, Faculty of Medicine, University of Airlangga, Dr. Soetomo General Hospital \\ Surabaya, Surabaya, East Java, Indonesia. \\ ${ }^{4}$ Department of Hematology, Faculty of Medicine, University of Airlangga, Dr. Soetomo General Hospital \\ Surabaya, Surabaya, East Java, Indonesia. \\ ${ }^{5}$ Department of Clinical Pathology, Faculty of Medicine, University of Airlangga, Dr. Soetomo General Hospital \\ Surabaya, Surabaya, East Java, Indonesia. \\ *Corresponding Author E-mail: hendriands@yahoo.com
}

\begin{abstract}
:
Retinoblastoma is a malignant retinal tumor associated with apoptotic deregulation. Retinoblastoma cells are sensitive to NK cells. These cells can stimulate apoptosis. Apoptosis in retinoblastoma occurs in the early phase and is paradoxical. The increasing amounts of $\mathrm{Bcl}-2$ and Caspase- 3 as apoptotic executors are inversely proportional to apoptosis. Calcium and ATP as second messengers and signaling molecules play role in mediating cell responses including retinoblastoma cell development and death. Apoptosis requires sufficient energy from ATP and its mediated by Calcium. This study aimed to perceive the effects of Calcium and ATP in the process of retinoblastoma cell death through Caspase-3 pathway. The subjects were poorly differentiated retinoblastoma cell cultures treated with NK cells (treatment group) compared to those which were not exposed to NK cells (control group). Through the cell flowcytometry test that expresses Caspase-3 and apoptosis is calculated, meanwhile the levels of Calcium and ATP activity produced during the apoptosis process are quantitatively calculated. Examination of ATP activity uses a colorimetric method while the calcium content is calculated using a clinical chemistry system. Calcium and ATP were negatively correlated at $27.4 \%$ ( $\mathrm{p}<0.05$ ). ATP also showed a very significant negative correlation of $75.8 \%(\mathrm{p}<0.01)$ against Caspase- 3 and is significantly positively correlated with apoptosis of $46.8 \%(\mathrm{p}, 0.05)$. Whereas Caspase- 3 is negatively correlated with apoptosis by $46.6 \%$ ( $\mathrm{p}<0.05$ ). In the Caspase-3 pathway, allogeneic NK cell administration in retinoblastoma cells increases the level of Calcium which plays a role in the early phase apoptosis process, whereas ATP which was formed is insufficient to cause maximal apoptosis due to extracellular calcium entry into NK cells. Extracellular ATP does not play a role in the induction of apoptosis in retinoblastoma cells treated with NK cells.
\end{abstract}

KEYWORDS: Allogeneic NK Cells, Caspase-3, Apoptosis, Calcium, ATP.

Received on 14.09.2018

Accepted on 20.11.2018

Research J. Pharm. and Tech. 2019; 12(3): 1307-1314

DOI: 10.5958/0974-360X.2019.00219.1

\section{INTRODUCTION:}

Retinoblastoma is a metastatic primary retinal malignant tumor in children. The incidence of retinoblastoma is about $4 \%$ of all malignancies in children. Many therapeutic methods performed on cases of retinoblastoma are still in the experimental stage however the results cannot improve the survival rate. 
Currently, the standard of therapy for retinoblastoma still includes surgery, radiotherapy and chemotherapy $y^{1,2,3,4}$.

Apoptosis is a process of programmed cell death that the body needs in maintaining hemostasis. If apoptosis deregulation occurs, the number of cells that divide will be higher than the death of the cell so that a tumor is formed. One cell that can affect the occurrence of apoptosis is the Natural Killer cell (NK cell) which has strong cytotoxic activity to respond to the immune cells of malignant tumors. NK cells are expected to suppress the growth and the spread of retinoblastoma cells ${ }^{5,6}$.

In retinoblastoma mutation occurs on chromosome 13q14 which causes increased proliferation and decreased apoptosis. In retinoblastoma, the apoptosis process is contrary with the apoptosis in general (paradox). Increases in Bcl-2 and Caspase- 3 as executors of apoptosis are inversely proportional to apoptosis. To cause cells undergoing apoptosis, sufficient energy is needed from ATP and mediated by Calcium ${ }^{7,8}$.

\section{MATERIAL AND METHODS:}

The subjects of this study were intratumoral retinoblastoma cultures collected from fresh tumor tissue which was enucleated. The histopathology test showed poorly differentiated retinoblastoma. This retinoblastoma cell culture will be divided into 2 groups, namely the control group that did not receive any therapy/exposure and the treatment group exposed to NK cells in vitro for 3 days. Then in each group the number of cells that express Caspase- 3 was calculated, and the Calcium and ATP levels occurring during the process were calculated.

\section{Retinoblastoma cell culture:}

Retinoblastoma tissue was washed with sterile PBS 3 times, chopped in collagenase free serum type I medium, incubated for 30 minutes at $37^{\circ} \mathrm{C}$, and subsequently the medium plus serum was added then filtered. Tissue were centrifugated at $1600 \mathrm{rpm}$ for 10 minutes, the supernatant removed and the pellet was resuspended with medium plus serum. After that culture was done on the plate until the culture was confluent. Repeated passage was done until a cell line was formed. Confluent cultures were divided into 2 groups, namely the control group which was not treated with allogeneic NK cells and the group treated at NK cells with a 1:1 ratio ${ }^{9}$.

\section{Culture and calculation of NK cell counts:}

Isolation (peripheral blood mononuclear cells/PBMC) was based on Boyum's method (1968) with several modifications. Three mls of venous blood sample for NK cell isolation was performed from the biological families of healthy retinoblastoma patients. Twenty $\mu \mathrm{L}$ of TriTEST ${ }^{\mathrm{TM}}$ CD3 FITC / CD16 + CD56 PE / CD45 PerCP reagent and $50 \mu \mathrm{L}$ of blood that was given $\mathrm{K}^{3} \mathrm{EDTA}$ was added into BD TruCOUNT tube. Reagents and blood samples are mixed with a vortex mixer. Reagent mixtures and blood samples were then incubated for 15 minutes at $20-25^{\circ} \mathrm{C}$ in a dark place. Added with $450 \mu \mathrm{L}$ BD FACS ${ }^{\mathrm{TM}}$ lysing solution, and then mixed with a vortex mixer. Furthermore incubated for 15 minutes at a temperature of $20-25^{\circ} \mathrm{C}$ in a dark places then proceeded with readings using BD FACSCalibur ${ }^{\mathrm{TM}}$. The number of NK cells was carried out by flowcytometry using BD FACS Calibur ${ }^{\mathrm{TM}}$, TriTEST ${ }^{\mathrm{TM}}$ CD3 Fluorescein Isothiocyanate (FITC)/CD16 ${ }^{+} \mathrm{CD} 56$ phycoerythrin (PE)/CD45 peridinin chlorophyll protein (PerCP) reagent, which is an immunofluoresce in color reagent to determine the number of $\mathrm{NK}$ cells (CD3-CD56 ${ }^{+}$) CD16 ${ }^{+}$. NK cells expressing CD3-CD56 ${ }^{+}$, CD16 ${ }^{+}$will florescence according to the area and then gating was performed gating. Gating was performed on NK cells in the expression area of $\mathrm{CD} 56^{+} / \mathrm{CD} 16^{+}$and areas without expression of $\mathrm{CD} 3\left(\mathrm{CD}^{-}\right)$. The number of NK cells (cells $/ \mu \mathrm{L}$ ) was obtained by calculating the cell event expressing $\mathrm{CD} 3-\mathrm{CD} 56^{+} / \mathrm{CD} 16^{+}$ratio with a known number of fluorescent bead events on BD TruCOUNT tubes ${ }^{10,11,12,13}$.

\section{Caspase-3 examination:}

Examination of cells expressing Caspase- 3 was carried out by flowcytometry using BD FACS Calibur ${ }^{\mathrm{TM}}$, Apoptosis FITC Active Caspase-3 reagent, BD Cytofix/ Cytoperm $^{\mathrm{TM}}$ dye reagent and BD Perm/Wash ${ }^{\mathrm{TM}}$ buffer reagent, and analyzed using flowcytometry. The number of Caspase-3 cell expressions (cell/ $\mu \mathrm{L}$ ) is obtained by calculating the event cell ratio with the known number of fluorescent bead events on the BD TruCOUNT tube ${ }^{10,12}$.

\section{Calcium examination:}

Quantitative Calcium examination used a SIEMENS

Dimension @ Clinical Chemistry System. Culture sampling, reagent delivery, mixing, processing and printing of results were automatically performed by the instrument. Sample culture were collected and processed according to the processing procedures available in the instrument instructions. Calcium was reacted with OCPC (O-Cresol phthalein Complexone) to form a purple complex. The number of complexes formed is proportional to the concentration of Calcium and measured using the bichromatic endpoint technique $(577,540 \mathrm{~nm})$. The results was then automatically be calculated by the instrument and printed the results in units of $\mathrm{mg} / \mathrm{dl}(\mathrm{mmol} / \mathrm{L})^{14,15}$.

\section{ATP Examination:}

Examination of ATP activity was carried out by a colorimetry method using the ATP Assay Kit

Elabscience $($ catalog No. E-BC-K157. Colorimetric method refers to a method based on color that results the reaction of colored compounds, by comparing or 
measuring colorful solutions based on Lambert's law. The initial step of ATP examination was to digest the culture cell sample and centrifuged at a rate of 1000$1500 \mathrm{r} / \mathrm{min}$ for 10 minutes, the supernatant was removed and the cell sediment was stored at a rate of approximately $10^{6} / \mathrm{mL}$ cells). To make a cell suspension 0.3-0.5 mL boiled double distilled water was added. The cell suspension was held in a boiling water bath for 10 minutes, then mixing and extracting was carried out for 1 minute. The sample was in a centrifuge at a speed of $3,500 \mathrm{r} / \mathrm{min}$, then the supernatant was taken to be detected. Then proceeded to prepare OD (optical density) sample, control, standard and blank as stated in the insert kit. For the results of the calculations the was used following formula

$=\underline{\text { ODsample }- \text { OD control }} \times$ concentration of standard $(1000$ mol/L) x Dilution factor of sample $\div$ Protein

OD standard - OD blank concentration of sample (gprot/L) 16,17.

\section{RESULTS:}

For the Retinoblastoma cell culture in the 2 groups, namely the control group without any treatment and the treatment group with each of 10 samples treated with NK cells cell calculations were performed which expressed Caspase-3 and apoptosis and examination of Calcium and ATP levels. Caspase- 3 examination was performed using the flowcytometry method and then the number of retinoblastoma cells expressing Caspase-3 was seen. The percentage of Caspase-3 expression of retinoblastoma culture cells in the control group and treatment group can be observed as percentage figures. There were significant differences in Caspase-3 expression between the two groups $(\mathrm{p}=0.00 ; \mathrm{p}<0.05)$.
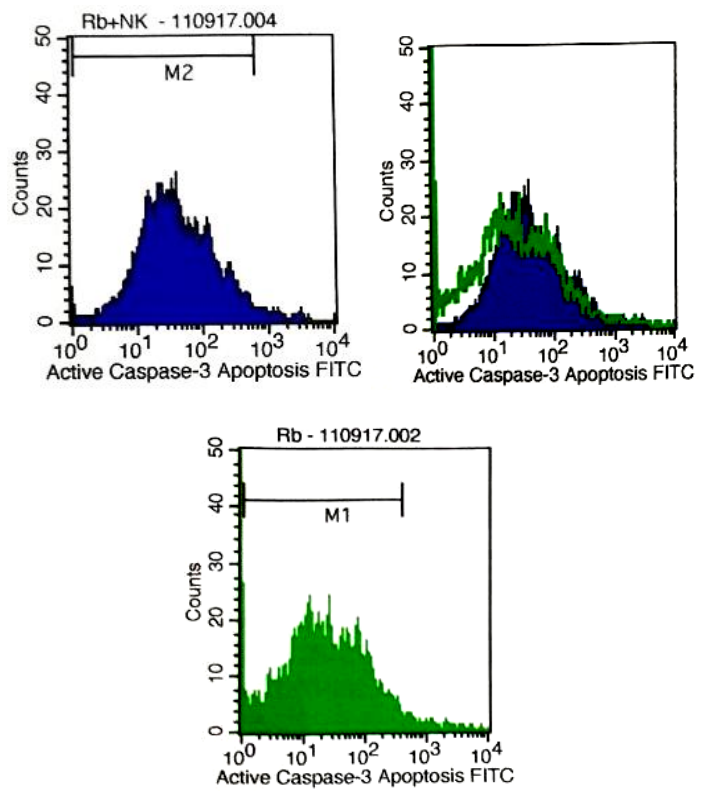

Figure 1. Results of Caspase-3 Flowcytometry in the Control (Rb) and Treatment Group (Rb + NK)
Apoptosis examination of retinoblastoma cells also used flowcytometry test. Flowcytometry test results used Annexin- $\mathrm{V}$ antibody to see the number of retinoblastoma cells expressing cell apoptosis in the early and late phases (Fig. 3). The percentage of early and late apoptosis in retinoblastoma culture cells in the control group and treatment group can be observed as percentage numbers (Fig. 2). Differences were obtained in early apoptosis expression in the control group and treatment group, that is in the control group at $19.75 \%$ and in the treatment group at $16.45 \%$ where a significant difference was found with $\mathrm{p}=0.00(\mathrm{p}<0.01)$. Whereas in the late apoptosis the control group was $5.34 \%$ and in the treatment group was $2 \%$ with a significant difference $(\mathrm{p}=0.00 ; \mathrm{p}<0.01)$.

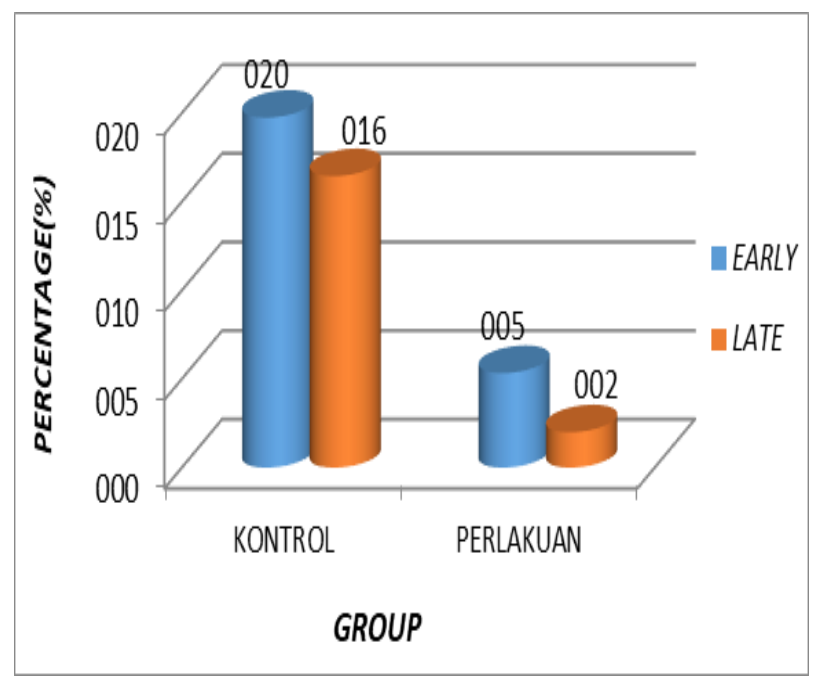

Figure 2. Percentage of Apoptosis of Retinoblastoma Culture Cells

From the results of the examination of Calcium levels it was shown that the average of the two groups was classified as low from the normal standard value. The treatment group was slightly higher than the control group. From the results of difference test the Independent $\mathrm{T}$-test showed that there were significant differences between the two groups $(\mathrm{p}=0.027 ; \mathrm{p}<0.05)$. In the ATP examination, ATP levels were calculated in sedimentation deposits of retinoblastoma culture cells. The test results of ATP levels were taken from the calculation of sample absorbance values compared to standard titrations and blanko. From the examination results of ATP levels, it was shown that mean value ofthe treatment group was higher than the control group. The results of Independent $\mathrm{T}$-tests showed that there were no statistically significant differences between two groups $(\mathrm{p}=0.000 ; \mathrm{p}<0.05)$. 

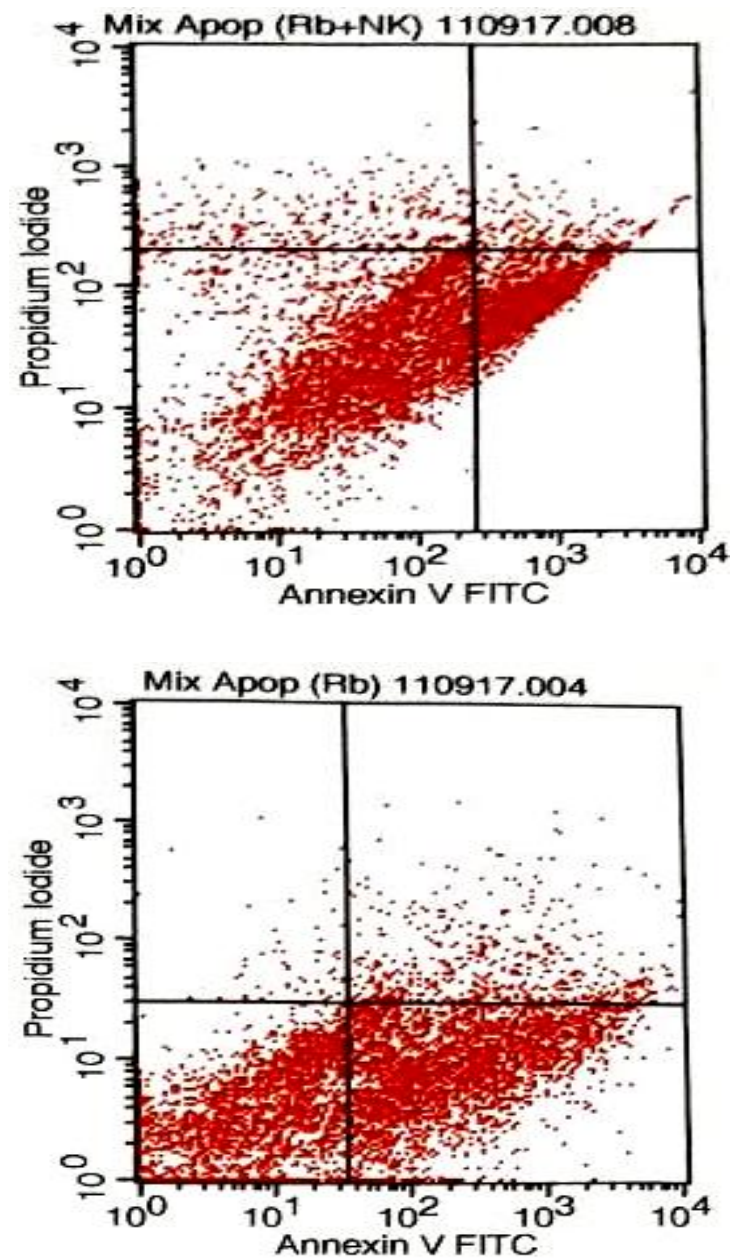

Figure 3. Results of Annexin-V Apoptosis Cell Flowcytometry in Control (Rb) and Treatment Group (Rb + NK)

Test results between the levels of Calcium, ATP levels, Caspase-3 expression, and Apoptosis of Retinoblastoma cells showed a negative correlation between Calcium and ATP $(p=-0.524 * ; p<0.05)$ and apoptosis $(p=-0.510$ *; $\mathrm{p}<0.05)$. ATP was also significantly negatively correlated with Caspase-3 ( $\mathrm{p}=-0.871 * * ; \mathrm{p}<0.01)$ yet ATP were significantly positively correlated with apoptosis $(\mathrm{p}=0.904 * * ; \mathrm{p}<0.01)$. Caspase-3 did not correlate with Calcium $(\mathrm{p}=0.443 ; \mathrm{p}>0.05)$ but was significantly negatively correlated with apoptosis $(\mathrm{p}=$ $0.899 * * ; \mathrm{p}<0.01)$. Path Analysis Test using regression showed that there was a significant negative correlation between the Calcium variables and ATP of $27.4 \%(\mathrm{~B}=-$ $0.274 * ; p<0.05)$. While the ATP variable also showed a very significant negative correlation of $75.8 \%(\mathrm{~B}=$ $0.758 * * ;<0.01)$ against Caspase- 3 and had a significant positive correlation with Apoptosis of $46.8 \%$ ( $\mathrm{B}=0.468$ $* ;<0.05)$. However, the Caspase-3 was negatively correlated with Apoptosis by $46.6 \% \quad(B=-0.466$ *; $\mathrm{p}<0.05)$.
Table 1: The Correlation Test Across Variables

\begin{tabular}{|l|l|l|l|l|}
\hline Variables & Calcium & ATP & Caspase-3 & Apoptosis \\
\hline Calcium & - & $\mathrm{p}=-$ & $\mathrm{p}=0.443$ & $\mathrm{p}=-$ \\
& & $0.524^{*}$ & & $0.510^{*}$ \\
\hline ATP & $\mathrm{p}=-$ & - & $\mathrm{p}=-0.871^{* *}$ & $\mathrm{p}=$ \\
& $0.524^{*}$ & & & $0.904^{* *}$ \\
\hline Caspase-3 & $\mathrm{p}=0.443$ & $\mathrm{p}=-$ & - & $\mathrm{p}=-$ \\
& & $0.871^{* *}$ & & $0.899^{* *}$ \\
\hline Apoptosis & $\mathrm{p}=-$ & $\mathrm{p}=$ & $\mathrm{p}=-$ & - \\
& $0.510^{*}$ & $0.904^{* *}$ & $0.899^{* *}$ & \\
\hline
\end{tabular}

(*) significant at $\alpha<0.05$

(**) significant at $\alpha<0.01$

\section{DISCUSSION:}

Characterization of retinoblastoma cell culture in the treatment group with allogeneic NK cells showed the formation of remnants of cells and NK cells surrounding the apoptotic cells. Soebagjo et al., (2015) reported that NK cells had the ability to induce retinoblastoma cells so that retinoblastoma cell growth in the treatment group was inhibited and generally experienced death. Therefore, there was a picture of NK cells around the apoptotic cells. On the contrary, in the control group retinoblastoma cells grew normally ${ }^{9,10}$.

Calcium $\left(\mathrm{Ca}^{2+}\right)$ is an important ion for cell life, acting as the second messenger that mediating various physiological responses of neurons. Calcium is also considered to be involved in cell death or apoptosis. Continuous increase in cytosolic Calcium can activate apoptosis. These ions can originate from extracellular influx or release of intracellular Calcium from its storage such as in the endoplasmic reticulum (Voccoli, 2014; Takadera, 2010). The results of examination of Calcium levels in this study indicated that the mean of the two groups was classified as low from the normal standard value. The treatment group is slightly higher than the control group, but it was said that there were differences between the two groups.

How does Calcium affect or kill cancer cells? Voccoli (2014) stated that the concentration of cytosolic Calcium can be modulated directly by channels and transporters importing Calcium into the cytosol or exporting it from the cytosol. There are three types of highly selective $\mathrm{Ca}^{2+}$ channels, namely the Calcium channel with voltage channels, TRPV5 / 6 channels and ORAI. Another very important aspect is the quantity of external calcium in cancerous tissue. Assumingly the extracellular free Calcium concentration is approximately same to the serum free Calcium, which is about $1.2 \mu \mathrm{M}$, but this is still remain unclear. However, fluctuations of this value can greatly affects cancer cell death by CTL and NK and CRAC channels. It means that small variations in extracellular Calcium level can significantly change the Calcium signal and Calcium-dependent target cells. Controlling external Calcium can greatly affect tumor growth but also efficiently kill CTL and NK cells, and this must be researched further ${ }^{18,19}$. 
Increased levels of extracellular Calcium in the RB group treated with NK cells are in line with the study by Takadera, et al., (2010) concerning the chelation of extracellular Calcium with EGTA. Takadera stated that the chelation of extracellular Calcium with EGTA induced apoptosis that depended on Caspase and activation of glycogen synthase kinase-3. Meanwhile Caspase- 3 would be inhibited by glycogen synthase kinase-3 inhibitors themselves. On the other hand, EGTA itself can increase cell death. While the study by Voccoli, et al., 2014 showed a different focus, it had the same view about the decreased levels of extracellular Calcium (by ethylenadiamine-tetraacetic acid agents) that could reduce intra-mitochondrial ROS production and improve cell viability ${ }^{17,18}$.

A previous research by Shenov, et al., 1993 stated that sensitive target cell interactions with human NK cells triggered the entry of extracellular calcium into NK cells. By using flowcytometry, it was proven that the maximum absorption of extracellular calcium delayed into NK cells caused dysfunction of the cells. Whereas the study of Lin K et al., (1998), stated otherwise that the Calcium-sensing receptor (CaR) acting as a Calciuminducing receptor could prevent apoptosis in prostate carcinoma cells and determined a new mechanism where these ions can ultimately regulate cell life $\mathrm{l}^{20,21}$.

Natural Killer Cells (NK) are known to mediate the innate immunity of infected cells. However, NK cells can also capture a number of special recall responses of a hapten. The research of Nguyen et al., (2017) showed that among the four known haptens, two haptens were known to induce NK cell-dependent $\mathrm{CHS}$ on the extracellular $\mathrm{Ca}^{2+}$ rapid entry to $\mathrm{NK}$ cells and lymphocyte cell lines, namely TRPC3 and TRPM3. The second hapten activity could result in changes in the concentration of $\mathrm{Ca}^{2+}$ ions in the cytosol and its intracellular storage resulting a change of the NK cell activation threshold. Increased intracellular $\mathrm{Ca}^{2+}$ concentration could help to improve NK cell cytotoxicity. Increased $\mathrm{Ca}^{2+}$-dependent $\mathrm{NK}$ activity could help to improve the immune system to facilitate a faster response to eliminate pathogenic conditions. In addition, increased cell-to-cell interactions could improve the development of antigen-specific memory cells $^{22,23}$.

ATP is a key extracellular signaling molecule and participates in several physiological processes, including the immune response, transmission of neurotransmission, vascular tone, pain sensation, proliferation, differentiation, development, and cell death. To carry out this function, ATP can act through two types of purine receptors namely $\mathrm{P} 2 \mathrm{X}$ receptors, which are ligand ion channels, and $\mathrm{P} 2 \mathrm{Y}$ receptors, which are G-G protein receptors combined ${ }^{24}$.

Apoptosis is a phenomenon that plays an important role in the process of cell development. Apoptosis can be induced by glucocorticoids and a number of different non physiological toxins, a common metabolic pathway in cell death because these various agents are yet to be fully understood. With the thought of the existence of a physiological ligand that might be easily exploited as a trigger for apoptosis, Zheng, et al. (1991) study described the morphological and biochemical characterization of cell death caused by extracellular ATP. Extracellular ATP induced programmed cell death (or apoptosis) in certain thymocytes and tumor cells, cervical cancer, and HPV infection ${ }^{24,25}$.

An electron microscope (EM) study showed that tumor thymocyte cell death and ATP-induced tumor cells followed morphological changes that usually occur along with glucocorticoid-induced apoptosis. ATP caused cell death through two different mechanisms. ATP-mediated cell lysis with DNA fragmentation and ATP cell induced a rapid increase in cytoplasmic calcium in susceptible cells. Calcium fluxes alone, however, were not sufficient to cause apoptosis, because pore-forming proteins, perforin, causing cell lysis without DNA fragmentation or morphological changes associated with apoptosis ${ }^{26}$.

Depending on the cell type, intracellular adenosine can induce apoptosis by the caspase-dependent orindependent mechanism. Tumor microenvironment which is rich in extracellular ATP and adenosine, and the effects of these molecules depend on ATP concentration and the rate of ATP degradation to adenosine by ectonucleotidases present in the extracellular membrane (as well as on P2 receptor panels expressed by tumors) ${ }^{27,28}$.

One of the most interesting aspects of the field is the role of ATP and other purine nucleotides in cell fate determination and the way it directs cells towards proliferation, differentiation or apoptosis, so that it may play role in promoting or preventing malignant transformation. In this review, the following is a brief introduction to the historical aspects of purinergic signals and a brief description of the structure and signal transduction pathways that are coupled to purinergic P2 receptors, the current theory of the possibility of how extracellular ATP can alter cell tumor cell function ${ }^{29,30}$.

Adenosine triphosphate (ATP) is actively released into the extracellular environment in response to tissue and cell damage. Through activation of P2X and P2Y receptors, extracellular ATP enhances tissue repair, increases the addition of immune and dendritic phagocytes, and acts as a NLR family activator, containing 3-cell inflammation (NLRP3). Conversion of 
extracellular ATP to adenosine, in contrast, which is essentially through enzymatic activity of CD39 and CD73 ectonucleotidase, acts as a negative feedback mechanism to prevent excessive immune responses. This study reviewed the effects of extracellular ATP and adenosine on tumorogenesis. First, we summarize the functions of extracellular ATP and adenosine in the context of tumor immunity. Second, we present an overview of the immunosuppressive and pro-angiogenic effects of extracellular adenosine. Third, we present experimental evidence that extracellular ATP and adenosine receptors are expressed by tumor cells and increase tumor growth. Conclusions from this study and several previous studies suggest that increasing ATPmediated activation of inflammasomes or inhibiting the accumulation of extracellular adenosine derived from tumors, can be an effective new way to induce anticancer activity $^{31}$.

ATP's anti-neoplastic activity was first demonstrated in the early 80s, where exogenous ATP inhibited the growth of pancreatic and colon cancer cells. Extracellular ATP is known to be unstable and can be hydrolyzed to other metabolic products, such as ADP, AMP and adenosine. Indeed, the prevention of ATP degradation with an extra-ATPase inhibitor has an adverse effect on ATP at higher concentrations. This observation leads us to question whether ATP and its degradation products have opposed the effects on breast cancer cells. This study found that in contrast to the effects of ATP, adenosine increases breast cancer cell migration, and this stimulatory effect is attenuated by adenosine receptor antagonists. This in vitro cell-based data was validated in vivo using a fat breast cancer xenograft model and a mouse model of intratibial bone metastasis. From the report for the first time, revealed the differential role and mechanism of ATP and its degradation products, adenosine, in the growth of breast cancer and metastasis. Therefore, ATP acts as a doubleedged sword in cancer growth and metastasis ${ }^{32,33}$.

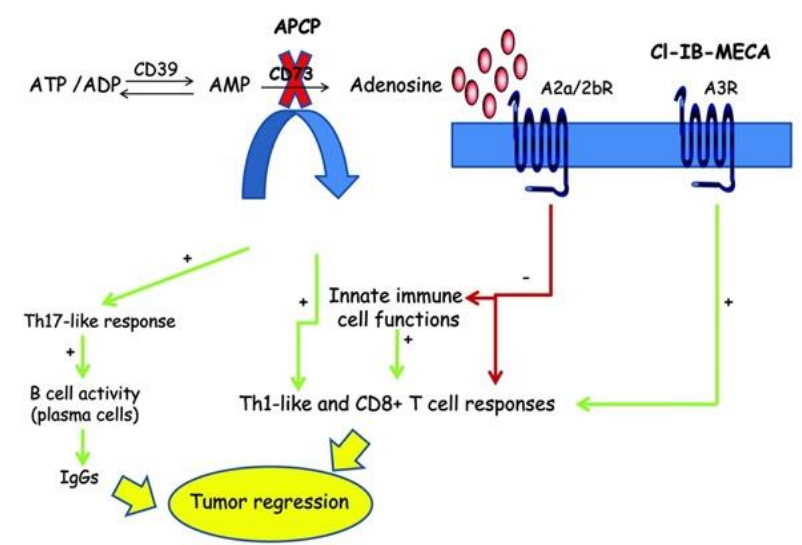

Figure 4. Involvement of adenosinergic signals in the development of cancer ${ }^{34}$.
Extracellular adenosine concentration remains constant in most of tissues but can increase rapidly to 100 times in response to hypoxia or inflammation, as in the microenvironment of solid tumors, where the concentration is increased compared with normal tissue. Adenosine increases the migration of cancer cells and chemotaxis to breast cancer cells and melanoma cells. The inhibitory effect on cancer cells by stimulating effects by ATP and adenosine mainly mediated by activation of $\mathrm{P} 2 \mathrm{X} 7$ and $\mathrm{A} 2 \mathrm{~A}$ receptor ${ }^{32}$.

Extracellular adenosine, which is released massively in cancerous tissue, is an important actor in regulation of immune cell activity, particularly through the involvement of $\mathrm{A}_{2 \mathrm{~A}}$ and $\mathrm{A}_{2 \mathrm{~B}}$ receptors. This is probably because the adenosine receptor system that is tightly regulated from immune cells is altered in cancer, thus combining these cells from immune surveillance and host defense activities towards neoplastic transformation and growth ${ }^{35}$.

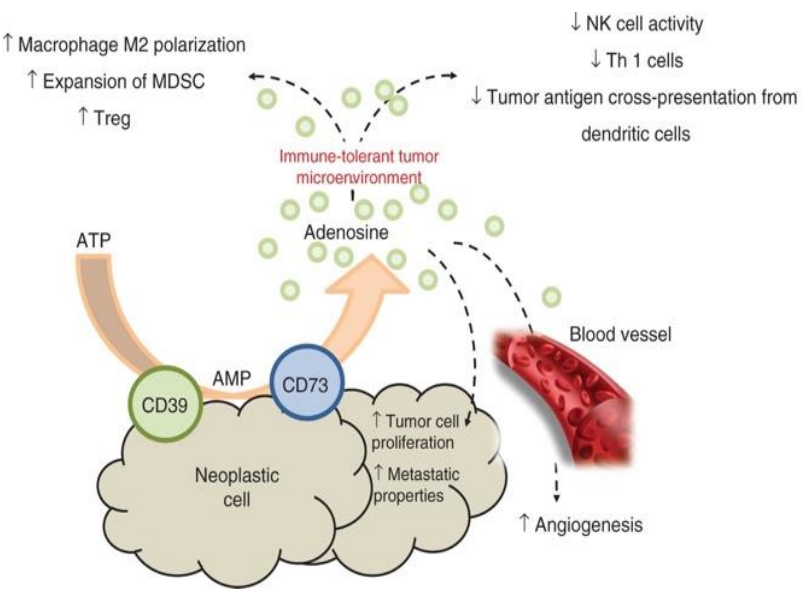

Figure 5. Schematic representation of the main action in the microenvironment of a tumor mediated by adenosine ${ }^{35}$.

Characteristic results in the group treated with NK cells showed that NK cells mostly gathered around retinoblastoma cells that experienced apoptosis. This shows that retinoblastoma cell death in the group treated with NK cells is capable of inducing retinoblastoma cell apoptosis. In the retinoblastoma cells culture streated with NK cells, retinoblastoma cells tend to grow sparsely and most experience apoptosis / cells experiencing death and many NK cells gather on the surface of the dead cells $^{11}$.

Caspase- 3 forms a fraction that is activated by $\mathrm{T}$ cells and is found in the cytoplasm of cells. In addition, according to $35 \mathrm{kDa}$ is also the molecular weight of the Caspase- 7 and pro Caspase- 9 pro. The process of cell death or apoptosis is commonly used as a selectivity parameter for an anti-cancer candidate. Induction of cell apoptosis is shown by an increase in the percentage of 
cells undergoing apoptosis. The results of the analysis showed that the mean early apoptosis in the treatment group was higher $(19.75 \%)$ compared to the control group $(16.45 \%)$ while in the late apoptosis the control group $(6.34 \%)$ was higher than the group (2\%). This shows that there is a role for NK cells in early apoptosis as shown in the previous study of Soebagjo etal., (2016). Cheng et al., (2013) mentioned the role of NK cells especially in the early stages of innate and adaptive immune system immunity. Poggi, et al., (2005) states that the trigger of apoptosis caused by NK cells will bind phosphatdylserine exposed to the surface of apoptotic cells and colored by Annexin-V in early apoptosis. In late apoptosis, it cannot be distinguished whether retinoblastoma cells or NK cells themselves according to Poggi, et al., (2005) will be effective in incubation for 24 hours and will reach a maximum point at 48 incubation periods with tumor cells (coculture) ${ }^{11,36,37,38}$.

That depiction shows the process of apoptotic signaling that occurs by allogeneic NK cells in retinoblastoma cells. In general, the process of NK cell apoptosis is carried out through 2 pathways: through NKG2D ligands on the intrinsic pathway or through TNF/FasL ligands on the extrinsic pathway. In NK cells, granzyme B plays the role. Pinkoski, etal., (2001) said that granzyme B was able to induce bypass apoptosis through Caspase-3. Granzyme B itself activated Apoptosis Bid pro protein and with Bax/Bak translocates to mitochondria and affected membrane permeability to release cytochrome$\mathrm{C}$ after apoptosome formation by caspase cascade ${ }^{39}$.

Moreover, Pinkoski et al., (2001) stated that in the direct pathway of granzyme B to Caspase-3, apoptosis through mitochondria can also occur via Smac/Diablo protein which mediated apoptosis of granzyme B and contributed to cell destruction by binding to XIAP. Furthermore, the release of Smac/Diablo in mitochondria would inhibit Bcl-2 $39,40,41$.

\section{CONCLUSION:}

The results of this study indicate that retinoblastoma cells are sensitive to allogeneic Natural Killer (NK) cells administration, particularly in the early apoptosis phase. These cells can trigger the entry of extracellular Calcium into NK cells so that the concentration is higher. Extracellular calcium is able to induce apoptosis depending on Caspase-3 so that cell death does not entirely occur. Meanwhile extracellular ATP does not play a role in the induction of apoptosis in retinoblastoma cells treated with NK cells.

\section{ACKNOWLEDGEMENT:}

The authors are grateful to the authorities of Faculty of Medicine, University of Airlangga and Dr. Soetomo General Hospital Surabaya, Surabaya, East Java, Indonesia.

\section{CONFLICT OF INTEREST:}

The authors declare no conflict of interest.

\section{REFERENCES:}

1. Stewart, BW and Wild, CP. World Cancer Report 2014. 2014. International Agency for Research on Cancer, Lyon

2. Dharmawidiarini, D, Prijanto, Soebagjo, HD. Ocular survival rate penderita retinoblastoma yang telah dilakukan enukleasi atau eksenterasi di RSUD Dr. Soetomo Surabaya. Media Jurnal Oftamlologi Indonesia. 2010. Vol.7. No.3.

3. Soebagjo, HD, R Prastyani, H Sujuti, D Lyrawati and SB Sumitro. Profile of Retinoblastoma in East Java, Indonesia. World Journal of Medicine and Medical Science Research. 2013. 1(3): 051-056

4. Ravi B, Sivabalan T. A study to evaluate the Quality of life in Head and Neck Cancer Patients admitted in Pravara Rural Hospital, Loni (Bk). Asian J. Nursing Edu. and Research. 2013; 3(1): 21-4

5. Kerimoğglu H, Kiratli H, Dinçtürk AA, Söylemezoğlu F, Bilgiç S. Quantitative analysis of proliferation, apoptosis, and angiogenesis in retinoblastoma and their association with the clinicopathologic parameters. Jpn J Ophthalmol. 2003;47: 565571.

6. Davis, CT, Rizzieri, D. Immunotherapeutic applications of NK $\begin{array}{llll}\text { cells. } & \text { Pharmaceuticals. 2015. } & \text { 8(2), 250-256. }\end{array}$ doi: $10.3390 / \mathrm{ph} 8020250$.

7. Ishikawa E, Tsuboi K, Saijo K, Harada H, Takano S, Nose T, et al. Autologous natural killer cell therapy for human recurrent malignant glioma. Anticancer Res 2004;24: 1861-71.

8. Knudson Jr., AG. Clinical Ophthalmic Oncology, Saunders Elesevier, Philadelphia. 2007. (335): pp1-16.

9. Sitorus, RS, S Gumay, PV Der Valk. The apoptosis paradox in retinoblastoma. Natural compounds and their role in apoptotic cell signaling pathways. Ann.N.Y. Acad.Sci. 2009. 1171: 77-86.

10. Soebagjo, HD, Fatmariyanti S, and Lutfi D. Effectiveness of Natural Killer (NK) cells in pheripheral blood stem cell towards expression of EZH2, Ki-67 and apoptosis in Retinoblastoma (RB) cells culture. Medicine Science, 2015. vol.04, pp.1-17.

11. Soebagjo, HD, Kusumastuti F, Jaya PR, Fatmariyanti S. Pengaruh sel Natural Killer Alogenik terhadap apoptosis, Bcl-2 dan Caspase-3 sel retinoblastoma. 2016. Fakultas Kedokteran, Universitas Airlangga.

12. Böyum A. Isolation of leucocytes from human blood. Further observations. Methylcellulose, dextran, and ficoll as erythrocyte aggregating agents. Scand J Clin Lab Invest Suppl. 1968; 97:3150

13. Jangde R An Overview of Resealed Erythrocyte for Cancer Therapy. Asian J. Res. Pharm. Sci. 2011; 1(4):83-92.

14. Hu P, Hegde M, Lennon PA. Modern Clinical Molecular Techniques. 2012. Springer, New York.

15. Sava, L, S Pillai, U More, A Sontakke. Serum calcium measurement: total versus free (ionized) calcium. Indian Journal of Clinical Biochemistry. 2005.20(2): 158-161.

16. Bowen, Raffick $A R$ and Alan $T$ Remaley. Interferences from blood collection tube components on clinical chemistry assays. $\begin{array}{lll}\text { Biochemia } & \text { Medica. 24(1):31-44 }\end{array}$ http://dx.doi.org/10.11613/BM.2014.006

17. Wang, J, L Wang, X Liu, Z Liang, S Song, W Li, G Li, C Fan. A Gold Nanoparticle-Based Aptamer Target Binding Readout for ATP Assay. Communication. Advanced Materials. 2007. 19(22): 3943-3946. https://doi.org/10.1002/adma.200602256

18. Méry, B, JB Guy, A Vallard, S Espenel, D Ardail, C RodriguezLafrasse, C Rancoule and N Magné. In Vitro Cell Death Determination for Drug Discovery: A Landscape Review of Real Issues. Journal of Cell Death. 2017. 1-8

19. Afroz A, Haque T, Talukder MU, Islam SMA. Spectrophotometric Estimation of Rosuvastatin Calcium and Glimepiride in Tablet Dosage Form. Asian J. Pharm. Ana. 2011; 1(4): 74-78. 
20. Takadera T, Ohtsuka M, Aoki H. Chelation of extracellular calcium-induced cell death was prevented by glycogen synthase kinase-3 inhibitors in PC12 cells. Cell Mol Neurobiol. 2010. Mar;30(2):193-8. doi: 10.1007/s10571-009-9442-y.

21. Voccoli V, Tonazzini, Signore G, Caleo M, Cecchini M. Role of extracellular calcium and mitochondrial oxygen species in psychosine-induced oligodendrocyte cell death. Cell Death \& Disease. 2014. 5e1529. doi: 10.1038/cddis.2014.483.

22. Nguyen T, Johnston S., Clarke L., Smith P, Staines D, MarshallGradisnik S. Impaired calcium mobilization in natural killer cells from chronic fatigue syndrome/myalgic encephalomyelitis patients is associated with transient receptor potential melastatin 3 ion channels. Clinical \&Experimental Immunology. 2017. Feb; 187(2): 284-293. Doi: 10.1111/cei.12882.

23. Bagilkar VV, Patil AA. Benefits of Stem Cells in Pediatrics. International Journal of Nursing Education and Research. 2017; 5(4): 377-380.

24. Zheng LM, Zychlinsky A, Liu C-C, Ojcius DM, Ding-E Young J. Extracellular ATP as a trigger for apoptosis or Programmed Cell Death. The Journal of Cell Biology. 1991. 112(2): 279-288.

25. Ganguly S. Effect of ATPase/ATP Synthetase inhibitors on As (III) biosorption by Aspergillus niger X300. Research J. Pharmacology and Pharmacodynamics. 2013; 5(4): 205-206.

26. Shenoy AM, Sidner RA, Brahmi Z. Signal transduction in cytotoxic lymphocytes: decreased calcium influx in NK cell inactivated with sensitive target cells. Cell Immunol. 1993. 147(2):294-301.

27. Lin K, Chattopadhyay N, Bai M, Alvarez R, Dang CV, Baraban JM, Brown EM, Ratan RR. Elevated Extracellular Calcium Can Prevent Apoptosis via the Calcium-Sensing Receptor. Biochemical and biophysical research communications. 1998. Vol.249, Issue 2, pp 325-331.

28. Paola AM, Eduardo CC, Jessica N, Aline B, Danielle BS. Adenosine uptake is the major effector of extracellular ATP toxicity in human cervical cancer cells. Mol. Biol. Cell. 2014. Oct 1; 25(19): 2905-2918. doi: 10.1091/mbc. E14-01-0042.

29. Deli, T and Csernoch L. Extracellular ATP and cancer: an overview with special reference to P2 purinergic receptors. Pathol. Oncol. Res. 2008.14: 219-231.

30. Jangde R. Matrix metalloproteinase: An overview. Research J. Science and Tech. 2011; 3(6): 304-310.

31. Stagg J and Smyth MJ. Extracellular adenosine triphosphate and adenosine in cancer. Oncogene. 2010. 29: 5346-5358. doi: 10.1038/onc.2010.292.

32. Jiang, Jean X, MA Riquelme, and JZ Zhou. ATP, a double-edged sword in cancer. Oncoscience. 2015. Vol.2, No.8. 1-2.

33. Pradeep S, Swati C, Ravindra D, Shweta P, Shilpi C, Tanushree C. Nanoparticles- Drug Delivery System in Cancer Therapy. Research J. Pharma. Dosage Forms and Tech. 2011; 3(2): 33-41.

34. Sorrentino R, Pinto A, and Morello S. The adenosinergic system in cancer. OncoImmunology, 2013. Vol.2, Issue 1. doi: 104161/onci.22448.

35. Antonioli L, Hasko G, Fornai M, Colucci R, Blandizzi C. Adenosine pathway and cancer: where do we go from here? Expert Opin Ther Targets. 2014.18(9): 973-7. doi: 10.1517/14728222.2014.925883.

36. Cheng, M, Chen Y, Xiao W, Sun R. NK cell-based immunotherapy for malignant diseases. Cell Mol Immunol, 2013.May; 10(3); 230-52. doi: 10.1038/cmi.2013.10.

37. Poggi, A, C Prevosto, AM Massaro, S Negrini, S Urbani, I Pierri, R Saccardi, M Gobbi, and MR Zocchi. Interaction between Human NK Cells and Bone Marrow Stromal Cells Induces NK Cell Triggering: Role of NKp30 and NKG2D Receptors. J Immunol. 2005.175(10) 6352-6360; DOI: https://doi.org/10.4049/jimmunol.175.10.6352

38. Dwivedi N, Dwivedi B, Mishra S, Shukla Y. Lupeol Induced Apoptosis in Human Lung Cancer Cell Line: A Flow Cytometry Study. Research Journal of Pharmacology and Pharmacodynamics. 2014; 6(4): 197-203.

39. Pinkoski MJ, Waterhouse NJ, Heibein JA, Wolf BB, Kuwana T, et al., Granzyme B-mediated apoptosis proceeds predominantly through a Bcl-2 inhibitatable mitochondrial pathway. J Biol Chem. 2001. Apr 13; 276(15): 1260-7. doi: 10.1074/jbc.M009038200.

40. Verhagen AM, Coulson EJ, Vaux DL. Inhibitor of apoptosis proteins and their relatives: IAPs and other BIRPs. Genome Biol. 2001. 2(7); Reviews3009. PMID: 11516343. PMCID: PMC139420.

41. Adrain C, Creagh EM, Martin SJ. Apoptosis-associated release of Smac/DIABLO from mitochondria requires active caspases and is blocked by Bcl-2. EMBO J. 2001. Dec 3: 20(23): 66276636. doi: 10.1093/emboj/20.23.6627. 
Reproduced with permission of copyright owner. Further reproduction prohibited without permission. 